\title{
Patriarchal Values of Indian womanhood and Its Legacy in Kalidas' Shakuntala
} Arun Ghorai

Research Assistant (ICSSR), Department of English, Mahishadal Raj College, Vidyasagar, University, India

\begin{abstract}
Over the course of centuries Indian great epics like the Ramayana and the Mahabharata continueto exert its pronounced impact upon shaping philosophic approach to Indian life on religious,cultural and social levels. The innovative andImmortal creation of theiconic figures like Rama and Krishna imparts strikingreligious and social stance to consolidate an enduring sense of moral consciousness.The present paper on the contrary seeks to explore how classical Indian philosophyinsists on defining Indian women as historically mute and socially oppressed subalternsubject under the patriarchal supervision. Therefore, the paper shades light on identifying the stereotype Indian women with Shakuntala whose womanhood is marked bycoyness,submissiveness and susceptibility. The prejudiced and paralytic patriarchal legacy left behind by post Vedic period perpetuates its ideologically galvanised exploitative encounter on thewomen.Though, neutralized in the wake of the globalization some extent the partial centralization of patriarchal power and authority does not allow the voiceless a valid and vast space to think independently of men in independent India.
\end{abstract}

Keywords-classical philosophy, womanhood, patriarchy and legacy.

Myth plays a critical role in shaping social, cultural and religious ethics of a country. Mythicalrepresentation of ideal female characters like Sita, savitri and Shakuntala attribute their social value and ideology to the perpetuation of hegemonic encounter upon the women of every subsequent centuries. Myth within and beyond India is generally held accountable for shaping socio-cultural landscape of any country. Classical literary aesthetics are enduringly contributory towards assigning the core constructional foundation to the cultural ethics. Mythical themes and ideal characters are instrumental effectively in operating the flawless intergenerational transmission of conventionally set socio-cultural specifics. Key to the perpetuation of mythical legacy correlates to valuing the myth as living embodiments of ideal, ideology and cultural values.

Kalidas is designated as most critically acclaimed classical dramatist in Indian literary scenario. His magnum opus "Shakuntala" is an ever relevant and dynamic creation transcending the spatio-temporal specificity. The character portrayal of Shakuntala adds to the play a rare degree of literary exclusivity. The thematic essence revolving around the classical approach to Indian Womanhood and patriarchal economy calls a critical attention. Shakuntala bykalidasa is a retelling on the story of king Dushyanta and his beloved Shakuntala, derived from the Mahabharata. The patriarchal social order set in post Vedic period is extensively projected in Shakuntala. The female protagonist Shakuntala including priyambada and Anusuya fall an innocent prey to the masculine oppression in the play.

Stereotype Indian women over centuries in Indian society convey a close resemblance to the protagonist Shakuntala whose ideal womanhood is traditionally marked by timidity and loyalty. With respect to this social value of women king Dushyanta says

"Hermit girls are by their very nature timid".

(Act-2)

Another commonplace female attributes of coyness and politeness are conventionally set as imperative traits of women. It becomes enduringly explicit in the words of the king -

"when I was near,she could not look at me".

(Act-2)

From classical period onwards female socializationrobs the women of their economic autonomy. They look compellingly dependant on men for their protection and advocacy. Themarriage of a woman is determined by the approval and disapproval of the patriarchal authority. In response to the suggestion of Clown to marry Shakuntala, king, Dushyantaspells out - 
"She is dependent on her father".

The root of this historical assumption about the treatment of women is possibly tradeable back to the Mahabharata wherein Gandhari's strict obedience to her father's prescriptive instruction paralysed her self -conscious assertion to deny the marriage with Dhritrasthra. Convetionaly a woman is exclusive of self-referentiality because she is not free of husband in marital life and the son during the physical infirmity. In A Vindication of the Rights of Woman, Wollstonecraft made a remark that patriarchy leads a woman to "a state of perpetual childhood. Insteada woman feels obliged to live up to the restrictive moral confines. They have a steely determination to be a dutiful, caring, submissive and devoted daughter and wife. The women traditionally devote their entire life to the service of their husbands and children. In A Roof of One's Own, Virginia Woolf argues

"women have served all these centuries as looking glasses..... natural size" (1945:5).

Reflecting the figure of man at twice its

The degree of female merginalisation under the patriarchal supervision turns more prominent as Sharnagarava claims:

"she is your wife

Husbands have power for good or ill

Over woman's life"(Act-5).

King Dushyanta's denial to recognize Shakuntala as his wife anticipates the synonymous oppression of Rani in the hand of her husband Alanna in Girish Kornad's Nagamandala.The critical patriarchal attitude towards mythical characters like Sita and Shakuntala looks closely identical with the $20^{\text {th }}$ century literary representation of stereotype Indian women Savitri in R K Narayana's The Dark Room (1938), Sarojini in Kamala Markandaya's A Silence of Desire (1963),Maya in Anita Desai's Cry the Peacock (1963), Saru in Sashi Despande's The Dark Holds No Terror.

The women over centuries areMaryWollstonecraft argues, 'formed in a mould of folly and deprived of being a rational creature ". Concerning it Indian great philosopher Swami Vivekananda asserted that a woman "is the fox,but when she is no longer oppressed, she will become a lion. The penetration of global economy into the remote areas of India has brought about a dramatic change to the social value of women in post-independence Indian society. But regarding the partial rootedness of patriarchal legacy,social scientist, Nadeem Hasnain remarks:
"Although some progress has been made, the basic attitude of Indian society towards women has not changed" (2013:468).

Human life is subject to heterosexuality. The distinction of sexual identity is not confined merely to the particularity of human life. Nature inescapably invests all creatures with this physical attributes. So the inevitability of this sexual plurality can hardly be contested by either of us. No one is born male or female. Society regularises an ideological bias to to define a female as not male right from the birth onwards. Concerning it ground-breaking feminist,Simon de Beauvoir made a pronouncement:

"one is not born but becomes a woman "

Men and women are inseparably important units of a societycontributing correspondingly to the solidification of a nation's backbone. But Indian women share a common history of patriarchal oppression. Society on the common ground of myth insists on defining Indian women as historically mute and socially oppressed subaltern subject under the patriarchal supervision. Social and cultural prejudices are still valued as a healthy moral framework within which ideal womanhood is evaluated. So the root of this social hierarchy is so deeply embedded in our social set up that the deprived and oppressed hardly afford to define the meaning of life beyond this prolonged and on going ideology. Regarding this prejudiced attitude towards the women, I agree with de Beauvoir's assertion that women lack a "positive definition ". In The Second Sex she claims:

"Humanity is male and man defines woman not in herself but as relative to him......he is the subject;he is the Absolute - she is the other ". $(1988: 16)$

But it is erroneous to some extent to hold the patriarchy as completely accountable for perpetuation of the hegemonic masculinity. They, in default of an enduring courage to cope with,feel terribly scared and ashamed of exceeding the boundaries of conventionally accepted socio-cultural specifics. A strict moral obligation to confirm with a set of ideologically embraced socio-cultural confines appears as an obstacle to the constitution of homogenous female stance. According to Wollstonecraft, the overarching drawback to the expression of self- reflectivity is the lack of access to the education. The men tactfully attribute their ideology to systematic enslaving to uphold the masculine supremacy and deny their direct accountability. It is the positive consent of women that allows the patriarchy to exert its authoritative subjectivity upon them.

The female rebellious response to the oppression is as old as the patriarchy is.But they are devoid of justice and equality for they look double-voiced and it splits the 
uniformity of protest. The collective and unidirectional strategic framework to maximise the emancipatory response can direct those self-contradictory victims to the discovery of their self-identity. Germaine Greer once made an agreeable assertion in relation to the possibility of female upgradation:

"women must learn how to question the most basic assumption about feminine normality in order to reopen the possibility for the development which has been locked off by conditioning “.(1991:17)

\section{CONCLUSION}

Their active participation in multiple cultural,economic and political interaction can elevate their indispensibility to an exemplary height. They,even in the wake of globalization can not respond to the hardly conquerable challenges of escaping the legacy of epics after an epic struggle over centuries. From 1947 onwards, the British raj is over but the raj of Bankimchandra's Rajmohan is not yet over in india. The partial centralization of patriarchal power and authority does not allow the voiceless a valid and vast space to think independently of men in independent India. The presence of 'he' within 'she', 'male' within 'female' and 'man' within 'woman ' is well reflexive of symbolic interdependence between the river and the rain. The men and women are to be correspondingly engaged to accelerate the economic competitiveness of a nation.

\section{REFERENCES}

[1] Chew, Shirley, A Concise Companion to Postcolonial Literature, Wiley-Blackwell 2010

[2] De Beauvoir, Simon, The Second Sex, London, Jonathan Cape 1953

[3] Hasnain, Nadeem, Indian Society and culture, JPD,New Delhi 2013

[4] Ryan,Michael, The Encyclopedia of Literary and Cultural Theory,Wiley-Blackwell 2011

[5] Wollstonecraft, Mary, A Vindication of the Rights of Woman,London,Penguin 1992

[6] W.Ryder, Arthur, Shakuntala (originally byKalidas) Cambridge, Ontario 1999 